\title{
METODE KOOPERATIF MODEL TEAM GAMES TOURNAMENT SEBAGAI ALTERNATIF MENINGKATKAN PRESTASI BELAJAR MATEMATIKA
}

\author{
Nurhasanah \\ Sekolah Dasar Negeri 6 Parit Pelang \\ Email: nurhasanahsdn6paritpelang@gmail.com
}

\begin{abstract}
Mathematics is a study on the materials that has abstract objects and is built through a process of deductive reasoning, that is, the truth of a concept is obtained as the logical consequence of the truth that has previously been received, so the interrelationship concepts in mathematics are very strong and clear. In learning mathematics to be easily understood by students, the process of deductive reasoning is to strengthen the understanding that is already owned by students. Mathematics Learning objectives are training how to think systematically, logically, critically, creatively and consistently. While the objectives of this study are: (a) to know the improvement of students' learning achievement after the application of the cooperative learning method of TGT model. (b) to know the effect of students' learning motivation after the application of the cooperative learning method of TGT model. From the results of analysis obtained, it was revealed that the students' achievement has increased from cycle I to cycle III that is, cycle I (66.67\%), cycle II (77.78\%), cycle III (88.89\%). In conclusion, this research provides a positive effect on learning motivation of Class V SDN 6 Parit Pelang students and this TGT model can be used as an alternative learning mathematics model.
\end{abstract}

\section{Keywords: mathematics, learning, TGT model, cooperative method}

\section{PENDAHULUAN}

Matematika merupakan suatu bahan kajian yang memiliki objek abstrak dan dibangun melalui proses penalaran deduktif, yaitu kebenaran suatu konsep diperoleh sebagai akibat logis dari kebenaran sebelumnya sudah diterima, sehingga keterkaitan antar konsep dalam matematika bersifat sangat kuat dan jelas.

Dalam pembelajaran matematika agar mudah dimengerti oleh siswa, proses penalaran deduktif untuk menguatkan pemahaman yang sudah dimiliki oleh siswa. Tujuan pembelajaran matematika adalah melatih cara berfikir secara sistematis, logis, kritis, kreatif dan konsisten.

Pembelajaran matematika tidak juga tidak lagi mengutamakan pada penyerapan melalui pencapaian informasi, tetapi lebih mengutamakan pada pengembangan kemampuan dan pemrosesan informasi. Untuk itu aktivitas peserta didik perlu ditingkatkan melalui latihan-latihan atau tugas matematika dengan bekerja kelompok kecil dan menjelaskan ide-ide kepada orang lain. (Hartoyo, 2000: 24).

Langkah-langkah tersebut memerlukan partisipasi aktif dari siswa. Untuk itu perlu ada metode pembelajaran yang melibatkan siswa secara langsung dalam pembelajaran. Adapun metode yang dimaksud adalah metode pembelajaan kooperatif. Pembelajaran kooperatif adalah suatu pengajaran yang melibatkan siswa bekerja dalam kelompok-kelompok untuk menetapkan tujuan bersama. Felder, (1994: 2).

Pembelajaran kooperatif lebih menekankan interaksi antar siswa. Dari sini siswa akan melakukan komunikasi aktif dengan sesama temannya. Dengan komunikasi tersebut diharapkan siswa dapat menguasai materi pelajaran dengan mudah karena "siswa lebih mudah memahami 
penjelasan dari kawannya dibanding penjelasan dari guru karena taraf pengetahuan serta pemikiran mereka lebih sejalan dan sepadan". (Sulaiman dalam Wahyuni 2001: 2).

Penelitian juga menunjukkan bahwa pembelajaran kooperatif memiliki dampak yang amat positif terhadap siswa yang rendah hasil belajarnya. (Nur, 1996: 2).

Pete Tschumi dari Universitas Arkansas Little Rock memperkenalkan suatu ilmu pengetahuan pengantar pelajaran komputer selama tiga kali, yang pertama siswa bekerja secara individu, dan dua kali secara kelompok. Dalam kelas pertama hanya 36\% siswa yang mendapat nilai $\mathrm{C}$ atau lebih baik, dan dalam kelas yang bekerja secara kooperatif ada 58\% dan 65\% siswa yang mendapat nilai $\mathrm{C}$ atau lebih baik (Felder, 1994:14).

Berdasarkan paparan tersebut diatas maka peneliti ingin mencoba Penerapan Metode Kooperatif Model TGT (Team Games Tournament) Sebagai Alternatif Meningkatkan Prestasi Belajar Matematika Pada Siswa Kelas melakukan penelitian dengan judul "Penerapan Metode Kooperatif Model TGT (Team Games Tournament) Sebagai Alternatif Meningkatkan Prestasi Belajar Matematika Pada Siswa Kelas V SDN 6 Parit Pelang Tahun Pelajaran 2019/2020"

Berdasarkan latar belakang di atas, maka dapat dirumuskan suatu masalah sebagai berikut: (1) Bagaimanakah peningkatan prestasi belajar siswa dengan diterapkannya metode pembelajaran kooperatif model TGT pada siswa kelas V SDN 6 Parit Pelang Tahun Pelajaran 2019/2020? (2) Bagaimanakah pengaruh metode pembelajaran kooperatif model TGT terhadap motivasi belajar siswa kelas Penerapan Metode Kooperatif Model TGT (Team Games Tournament) Sebagai Alternatif Meningkatkan Prestasi Belajar Matematika Pada Siswa Kelas V SDN 6 Parit Pelang Tahun Pelajaran 2019/2020?

Sesuai dengan permasalahan di atas, penelitian ini bertujuan untuk: (1) Ingin mengetahui peningkatan prestasi belajar siswa setelah diterapkannya metode pembelajaran kooperatif model TGT pada siswa Kelas V SDN 6 Parit Pelang Tahun Pelajaran 2019/2020. (2) Ingin mengetahui pengaruh motivasi belajar siswa setelah diterapkan metode pembelajaran kooperatif model TGT pada siswa kelas Kelas V SDN 6 Parit Pelang Tahun Pelajaran 2019/2020.

Penelitian ini dapat memberikan manfaat bagi: (1) Sekolah sebagai penentu kebijakan dalam upaya meningkatkan prestasi belajar siswa khususnya pada mata pelajaran matematika. (2) Guru, sebagai bahan pertimbangan dalam menentukan metode pembelajaran yang dapat memberikan manfaat bagi siswa. (3) Siswa, dapat meningkatkan motivasi belajar dan melatih sikap sosial untuk saling peduli terhadap keberhasilan siswa lain dalam mencapai tujuan belajar. (4) Meningkatkan belajar siswa pada pelajaran matematika. (5) Mengembangkan model pembelajaran yang sesuai.

Pembelajaran adalah proses, cara, menjadikan orang atau makhluk hidup belajar. Sedangkan belajar adalah berusaha memperoleh kepandaian atau ilmu, berubah tingkah laku atau tanggapan yang disebabkan oleh pengalaman. (KBBI, 1996: 14).

Sependapat dengan pernyataan tersebut Sutomo (1993: 68) mengemukakan bahwa pembelajaran adalah proses pengelolaan lingkungan seseorang yang dengan sengaja dilakukan sehingga memungkinkan dia belajar untuk melakukan atau mempertunjukkan tingkah laku tertentu pula. Sedangkan belajar adalah suatu peoses yang menyebabkan perubahan tingkah laku yang bukan disebabkan oleh proses pertumbuhan yang bersifat fisik, tetapi perubahan dalam kebiasaan, kecakapan, bertambah, berkembang daya pikir, sikap dan lain-lain. (Soetomo, 1993: 120).

Jadi pembelajaran adalah proses yang disengaja yang menyebabkan siswa belajar pada suatu lingkungan belajar untuk melakukan kegiatan pada situasi tertentu.

Pembelajaran kooperatif adalah suatu pengajaran yang melibatkan siswa untuk bekerja dalam kelompok-kelompok untuk 
menetapkan tujuan bersama. (Felder, 1994: 2).

Wahyuni (2001: 8) menyebutkan bahwa pembelajaran kooperatif merupakan strategi pembelajaran dengan cara menempatkan siswa dalam kelompok-kelompok kecil yang memiliki kemampuan berbeda.

Sependapat dengan pernyataan tersebut Setyaningsih (2001: 8) mengemukakan bahwa metode pembelajaran kooperatif memusatkan aktivitas di kelas pada siswa dengan cara pengelompokan siswa untuk bekerjasama dalam proses pembelajaran.

Dari tiga pengertian di atas dapat disimpulkan bahwa pembelajaran kooperatif adalah suatu metode pembelajaran dengan cara mengelompokkan siswa ke dalam kelompok-kelompok kecil untuk bekerja sama dalam memecahkan masalah. Kemampuan siswa dalam setiap kelompok adalah hiterogen.

Dalam pembelajaran kooperatif siswa tidak hanya sebagai objek belajar tetapi menjadi subjek belajar karena mereka dapat berkreasi secara maksimal dalam proses pembelajaran. Hal ini terjadi karena pembelajaran kooperatif merupakan metode alternatif dalam mendekati permasalahan, mampu mengerjakan tugas besar, meningkatkan keterampilan komunikasi dan sosial, serta perolehan kepercayaan diri.

Dalam pembelajaran ini siswa saling mendorong untuk belajar, saling memperkuat upaya-upaya akademik dan menerapkan norma yang menunjang pencapaian hasil belajar yang tinggi. (Nur, 1996: 4). Dalam pembelajaran kooperatif lebih mengutamakan sikap sosial untuk mencapai tujuan pembelajaran yaitu dengan cara kerjasama.

Pembelajaran kooperatif mempunyai unsur-unsur yang perlu diperhatikan. Unsurunsur tersebut sebagai berikut: (1) Para siswa harus memiliki persepsi bahwa mereka "tenggelam atau berenang bersama". (2) Para siswa memiliki tanggungjawab terhadap siswa lain dalam kelompoknya, disamping tanggungjawab terhadap dirinya sendiri, dalam mempelajari materi yang dihadapi. (3) Para siswa harus berpandangan bahwa mereka semuanya memiliki tujuan yang sama. (4) Para siswa harus membagi tugas dan berbagai tanggungjawab sama besarnya diantara para anggota kelompok. (5) Para siswa akan diberikan satu evaluasi atau penghargaan yang akan ikut berpengaruh terhadap evaluasi seluruh anggota kelompok. (6) Para siswa berbagi kepemimpinan sementara mereka memperoleh keterampilan bekerjasama selama belajar. (7) Para siswa akan diminta mempertanggungjawabkan secara individual materi yang ditangani dalam kelompok kooperatif.

Johnson, Johnson, dan Smitt dalam Felder (1994: 2) menambahkan unsur-unsur dalam pembelajaran koopratif sebagai berikut: (1) Ketergantungan Positif. Anggota kelompok harus saling tergantung untuk mencapai tujuan. Jika ada anggota yang gagal mengerjakan tugasnya maka setiap anggota harus menerima konsekuensinya. Kemampuan Individual. Seluruh siswa dalam satu kelompok memiliki tanggung jawab melakukan pekerjaannya dan menguasai seluruh bahan untuk dipelajari. (3) Promosi tatap muka interaktif. Meskipun beberapa kelompok kerja dibagi-bagikan dan dilakukan tiap individu, beberapa diantarannya harus dilakukan secara interaktif, anggota kelompok saling memberikan timbal balik. (4) Manfaat dari penggabungan keahliah yang tepat. Siswa didorong dan dibantu untuk mengembangkan dan mempraktekkan pembangunan kepercayaan, kepemimpinan, pembuatan keputusan, komunikasi dan konflik manajemen keahlian. (5) Kelompok Proses. Anggota kelompok mengatur kelompok, secara periodik menilai apa yang mereka lakukan dengan baik sebagai sebuah kelompok dan mengidentifikasi perubahan yang akan mereka lakukan agar fungsi mereka lebih efektif di waktu selanjutnya.

\section{METODE PENELITIAN}

Penelitian ini merupakan penelitian tindakan (action research), karena penelitian dilakukan untuk memecahkan masalah pembelajaran di kelas. Penelitian ini juga termasuk penelitian deskriptif, sebab menggambarkan bagaimana suatu teknik 
pembelajaran diterapkan dan bagaimana hasil yang diinginkan dapat dicapai.

Menurut Oja dan Sumarjan (dalam Titik Sugiarti, 1997: 8) mengelompokkan penelitian tindakan menjadi empat macam yaitu, (a) guru sebagai peneliti; (b) penelitian tindakan kolaboratif; (c) simultan terintegratif; (d) administrasi sosial eksperimental.

Dalam penelitian tindakan ini menggunakan bentuk guru sebagai peneliti, penanggung jawab penuh penelitian ini adalah guru. Tujuan utama dari penelitian tindakan ini adalah untuk meningkatkan hasil pembelajaran di kelas dimana guru secara penuh terlibat dalam penelitian mulai dari perencanaan, tindakan, pengamatan, dan refleksi.

Dalam penelitian ini peneliti tidak bekerjasama dengan siapapun, kehadiran peneliti sebagai guru di kelas sebagai pengajar tetap dan dilakukan seperti biasa, sehingga siswa tidak tahu kalau diteliti. Dengan cara ini diharapkan didapatkan data yang seobjektif mungkin demi kevalidan data yang diperlukan.

Tempat penelitian adalah tempat yang digunakan dalam melakukan penelitian untuk memperoleh data yang diinginkan. Penelitian ini bertempat di SDN 6 Parit Pelang Kecamatan Teluk Batang Kabupaten Kayong Utara Provinsi Kalimantan Barat.

Waktu penelitian adalah waktu berlangsungnya penelitian atau saat penelitian ini dilangsungkan. Penelitian ini dilaksanakan pada bulan Agustus sampai dengan November semester ganjil tahun pelajaran 2019/2020

Subyek penelitian adalah siswa-siswi Kelas V SDN 6 Parit Pelang Tahun Pelajaran 2019/2020 pokok bahasan pengukuran

Penelitian ini menggunakan Penelitian Tindakan Kelas (PTK). Menurut Tim Pelatih Proyek PGSM, PTK adalah suatu bentuk kajian yang bersifat reflektif oleh pelaku tindakan yang dilakukan untuk meningkatkan kemantapan rasional dari tindakan mereka dalam melaksanakan tugas, memperdalam pemahaman terhadap tindakan-tindakan yang dilakukan itu, serta memperbaiki kondisi dimana praktek pembelajaran tersebut dilakukan (dalam Mukhlis, 2000: 3).

Sedangkah menurut Mukhlis (2000: 5) PTK adalah suatu bentuk kajian yang bersifat sistematis reflektif oleh pelaku tindakan untuk memperbaiki kondisi pembelajaran yang dilakukan.

Adapun tujuan utama dari PTK adalah untuk memperbaiki/meningkatkan pratek pembelajaran secara berkesinambungan, sedangkan tujuan penyertaannya adalah menumbuhkan budaya meneliti di kalangan guru (Mukhlis, 2000: 5).

Instrumen yang digunakan dalam penelitian ini terdiri dari: (1) Silabus :Yaitu seperangkat rencana dan pengaturan tentang kegiatan pembelajaran pengelolahan kelas, serta penilaian hasil belajar. (2) Rencana Pelajaran (RP) : Yaitu merupakan perangkat pembelajaran yang digunakan sebagai pedoman guru dalam mengajar dan disusun untuk tiap putaran. Masing-masing RP berisi kompetensi dasar, indikator pencapaian hasil belajar, tujuan pembelajaran khusus, dan kegiatan belajar mengajar. (3) Lembar Kegiatan Siswa : Lembar kegiatan ini yang dipergunakan siswa untuk membantu proses pengumpulan data hasil eksperimen. (4) Lembar Observasi Kegiatan Belajar Mengajar: (a) Lembar observasi pengolahan metode pembelajaran kooperatif model TGT, untuk mengamati kemampuan guru dalam mengelola pembelajaran. (b) Lembar observasi aktivitas siswa dan guru, untuk mengamati aktivitas siswa dan guru selama proses pembelajaran.

Tes ini disusun berdasarkan tujuan pembelajaran yang akan dicapai, digunakan untuk mengukur kemampuan pemahaman konsep matematika pokok bahasan pengukuran Tes formatif ini diberikan setiap akhir putaran. Bentuk soal yang diberikan adalah pilihan ganda (objektif).

Data-data yang diperlukan dalam penelitian ini diperoleh melalui observasi pengolahan metode pembelajaran kooperatif model TGT, observasi aktivitas siswa dan guru angket motivasi siswa, dan tes formatif.

Untuk mengetahui keefektivan suatu metode dalam kegiatan pembelajaran perlu 
diadakan analisa data. Pada penelitian ini menggunakan teknik analisis deskriptif kualitatif, yaitu suatu metode penelitian yang bersifat menggambarkan kenyataan atau fakta sesuai dengan data yang diperoleh dengan tujuan untuk mengetahui prestasi belajar yang dicapai siswa juga untuk memperoleh respon siswa terhadap kegiatan pembelajaran serta aktivitas siswa selama proses pembelajaran.

Untuk mengalisis tingkat keberhasilan atau persentase keberhasilan siswa setelah proses belajar mengajar setiap putarannya dilakukan dengan cara memberikan evaluasi berupa soal tes tertulis pada setiap akhir putaran.

\section{HASIL DAN PEMBAHASAN PENELITIAN \\ Siklus I}

Pada tahap ini peneliti mempersiapkan perangkat pembelajaran yang terdiri dari rencana pelajaran 1 , LKS 1 , soal tes formatif 1 dan alat-alat pengajaran yang mendukung. Selain itu juga dipersiapkan lembar observasi pengolahan metode pembelajaran kooperatif model TGT, dan lembar observasi aktivitas guru dan siswa.

Pelaksanaan kegiatan belajar mengajar untuk siklus I dilaksanakan pada tanggal 10 September 2019 di kelas V dengan jumlah siswa 27 siswa. Dalam hal ini peneliti bertindak sebagai guru. Adapun proses belajar mengajar mengacu pada rencana pelajaran yang telah dipersiapkan. Pengamatan (observasi) dilaksanakan bersamaan dengan pelaksaaan belajar mengajar.

Pada akhir proses belajar mengajar siswa diberi tes formatif I dengan tujuan untuk mengetahui tingkat keberhasilan siswa dalam proses belajar mengajar yang telah dilakukan. Adapun data hasil penelitian pada siklus I adalah sebagai berikut:

Tabel 1. Pengelolaan Pembelajaran Pada Siklus I

\begin{tabular}{|c|c|c|c|c|}
\hline \multirow{2}{*}{ No } & \multirow{2}{*}{ Aspek yang diamati } & \multicolumn{2}{|c|}{ Penilaian } & \multirow{2}{*}{ Rata-rata } \\
\hline & & P1 & $\mathbf{P 2}$ & \\
\hline \multirow{16}{*}{ I } & Pengamatan KBM & & & \\
\hline & A. Pendahuluan & & & \\
\hline & 1. Memotivasi siswa & 0 & & 0 \\
\hline & 2. Menyampaikan tujuan pembelajaran & 2 & 2 & 2 \\
\hline & 3. Menghubungkan dengan pelajaran & & & 2 \\
\hline & sebelumnya & & & \\
\hline & $\begin{array}{l}\text { 4. Mengatur siswa dalam kelompok-kelompok } \\
\text { belajar }\end{array}$ & & & \\
\hline & B. Kegiatan inti & & & \\
\hline & $\begin{array}{l}\text { 1. Mempresentasikan langkah-langkah metode } \\
\text { pembelajaran kooperatif }\end{array}$ & 3 & 3 & 3 \\
\hline & 2. Membimbing siswa melakukan kegiatan & 3 & 3 & 3 \\
\hline & 3. Melatih keterampilan kooperatif & 3 & 3 & 3 \\
\hline & 4. Mengawasi setiap kelompok secara bergiliran & & & \\
\hline & $\begin{array}{l}\text { 5. Memberikan bantuan kepada kelompok yang } \\
\text { mengalami kesulitan }\end{array}$ & 3 & 3 & 3 \\
\hline & C. Penutup & & & \\
\hline & 1. Membimbing siswa membuat rangkuman & 3 & 3 & 3 \\
\hline & 2. Memberikan evaluasi & 3 & 3 & 3 \\
\hline II & Pengelolaan Waktu & 2 & 2 & 2 \\
\hline III & Antusiasme Kelas & & & \\
\hline & 1. Siswa antusias & 2 & 2 & 2 \\
\hline
\end{tabular}




\begin{tabular}{cccc}
\hline 2. Guru antisias & 3 & 3 & 3 \\
\hline Jumlah & 32 & 32 & 32 \\
\hline
\end{tabular}

Berdasarkan tabel di atas aspek-aspek yang mendapatkan kriteria kurang baik adalah memotivasi siswa, menyampaikan tujuan pembelajran, pengelolaan waktu, dan siswa antusias. Keempat aspek yang mendapat nilai kurang baik di atas, merupakan suatu kelemahan yang terjadi pada siklus I dan akan dijadikan bahan kajian untuk refleksi dan revisi yang akan dilakukan pada siklus II. Hasil observasi berikutnya adalah aktivitas guru dan siswa seperti pada tabel berikut:

\section{Tabel 2. Pengelolaan Pembelajaran Pada Siklus I}

\begin{tabular}{clc}
\hline No & \multicolumn{1}{c}{ Aktivitas Guru yang diamati } & Presentase \\
\hline 1 & Menyampaikan tujuan & 5,0 \\
2 & Memotivasi siswa & 8,3 \\
3 & Mengkaitkan dengan pelajaran sebelumnya & 8,3 \\
4 & Menyampaikan materi/ langkah-langkah/ strategi & 6,7 \\
5 & Menjelaskan materi yang sulit & 13,3 \\
6 & Membimbing dan mengamati siswa dalam menemukan konsep & 21,7 \\
7 & Meminta siswa menyajikan dan mendiskusikan hasil kegiatan & 10,0 \\
8 & Memberikan umpan balik & 18,3 \\
9 & Membimbing siswa merangkum pelajaran & 8,3 \\
\hline No & \multicolumn{1}{c}{ Aktivitas siswa yang diamati } & Presentase \\
\hline 1 & Mendengarkan/ memperhatikan penjelasan guru & 22,5 \\
2 & Membaca buku & 11,5 \\
3 & Bekerja dengan sesama anggota kelompok & 18,7 \\
4 & Diskusi antar siswa/ antara siswa dengan guru & 14,4 \\
5 & Menyajikan hasil pembelajaran & 2,9 \\
6 & Menyajikan/ menanggapi pertanyaan/ ide & 5,2 \\
7 & Menulis yang relevan dengan KBM & 8,9 \\
8 & Merangkum pembelajaran & 6,9 \\
9 & Mengerjakan tes evaluasi & 8,9 \\
\hline
\end{tabular}

Berdasarkan tabel di atas tampak bahwa aktivitas guru yang paling dominan pada siklus I adalah membimbing dan mengamati siswa dalam menemukan konsep, yaitu 21,7 $\%$. Aktivitas lain yang presentasinya cukup besar adalah memberi umpan balik/ evaluasi, tanya jawab dan menjelaskan materi yang sulit yaitu masing-masing sebesar 13,3\%. Sedangkan aktivitas siswa yang paling dominan adalah mengerjakan/ memperhatikan penjelasan guru yaitu $22,5 \%$. Aktivitas lain yang presentasinya cukup besar adalah bekerja dengan sesama anggota kelompok, diskusi antara siswa/ antara siswa dengan guru, dan membaca buku yaitu masing-masing 18,7 \% 14,4 dan 11,5\%.

Pada siklus I, secaraa garis besar kegiatan belajar mengajar dengan metode pembelajaran kooperatif model TGT sudah dilaksanakan dengan baik, walaupun peran guru masih cukup dominanuntuk memberikan penjelasan dan arahan, karena model tersebut masih dirasakan baru oleh siswa. 
Table 3. Nilai Tes Formatif Pada Siklus I

\begin{tabular}{|c|c|c|c|c|c|c|c|}
\hline \multirow{2}{*}{$\begin{array}{l}\text { No. } \\
\text { Urut }\end{array}$} & \multirow{2}{*}{ Skor } & \multicolumn{2}{|c|}{ Keterangan } & \multirow{2}{*}{$\begin{array}{l}\text { No. } \\
\text { Urut }\end{array}$} & \multirow{2}{*}{ Skor } & \multicolumn{2}{|c|}{ Keterangan } \\
\hline & & $\mathbf{T}$ & TT & & & $\mathbf{T}$ & TT \\
\hline & & & & Jumlah & 860 & 8 & 5 \\
\hline Jumlah & 930 & 10 & 4 & & & & \\
\hline $\begin{array}{l}\text { Jumlah } S \\
\text { Jumlah } S \\
\text { Rata-Rat }\end{array}$ & $\begin{array}{l}\text { simal } \\
\text { rcapa }\end{array}$ & & & & & & \\
\hline
\end{tabular}

Tabel 4. Rekapitulasi Hasil Tes Formatif Pada Siklus I

\begin{tabular}{clc}
\hline No & \multicolumn{1}{c}{ Uraian } & Hasil Siklus I \\
\hline 1 & Nilai rata-rata tes formatif & 66,30 \\
2 & Jumlah siswa yang tuntas belajar & 18 \\
3 & Persentase ketuntasan belajar & 66,67 \\
\hline
\end{tabular}

Dari tabel di atas dapat dijelaskan bahwa dengan menerapkan metode pembelajaran kooperatif model TGT diperoleh nilai ratarata prestasi belajar siswa adalah 66,30 dan ketuntasan belajar mencapai $66,67 \%$ atau ada 18 siswa dari 27 siswa sudah tuntas belajar. Hasil tersebut menunjukkan bahwa pada siklus pertama secara klasikal siswa belum tuntas belajar, karena siswa yang memperoleh nilai $\geq 65$ hanya sebesar $66,67 \%$ lebih kecil dari persentase ketuntasan yang dikehendaki yaitu sebesar $85 \%$. Hal ini disebabkan karena siswa masih merasa baru dan belum mengerti apa yang dimaksudkan dan digunakan guru dengan menerapkan metode pembelajaran kooperatif model TG

Tabel 5. Pengelolaan Pembelajaran Pada Siklus II

\begin{tabular}{|c|c|c|c|c|}
\hline \multirow{2}{*}{ No } & \multirow{2}{*}{ Aspek yang diamati } & \multicolumn{2}{|c|}{ Penilaian } & \multirow{2}{*}{ Rata-rata } \\
\hline & & P1 & $\mathbf{P 2}$ & \\
\hline \multirow{16}{*}{ I } & Pengamatan KBM & & & \\
\hline & D. Pendahuluan & & & \\
\hline & 1. Memotivasi siswa & 3 & 3 & 3 \\
\hline & 2. Menyampaikan tujuan pembelajaran & 3 & 4 & 3,5 \\
\hline & 3. Menghubungkan dengan pelajaran sebelumnya & & & \\
\hline & 4. Mengatur siswa dalam kelompok-kelompok belajar & & & \\
\hline & E. Kegiatan inti & 3 & 4 & 35 \\
\hline & 1. Mempresentasikan langkah-langkah metode & $\begin{array}{l}3 \\
4\end{array}$ & $\begin{array}{l}4 \\
4\end{array}$ & $\begin{array}{c}5,5 \\
4\end{array}$ \\
\hline & pembelajaran kooperatif & 4 & 4 & 4 \\
\hline & 2. Membimbing siswa melakukan kegiatan & & & \\
\hline & 2. Melatih keterampilan kooperatif & 4 & 4 & 4 \\
\hline & 3. Mengawasi setiap kelompok secara bergiliran & 4 & 4 & 4 \\
\hline & $\begin{array}{l}\text { 4. Memberikan bantuan kepada kelompok yang } \\
\text { mengalami kesulitan }\end{array}$ & 3 & 3 & 3 \\
\hline & A. Penutup & & & \\
\hline & 1. Membimbing siswa membuat rangkuman & 3 & 4 & 3,5 \\
\hline & 2. Memberikan evaluasi & 4 & 4 & 4 \\
\hline II & Pengelolaan Waktu & 3 & 3 & 2 \\
\hline
\end{tabular}




\begin{tabular}{cccccc}
\hline \multicolumn{2}{c}{ Antusiasme Kelas } & & & \\
III & 1. & Siswa antusias & 4 & 3 & 3,5 \\
& 2. & Guru antisias & 4 & 4 & 4 \\
\hline \multicolumn{2}{c}{ Jumlah } & 41 & 43 & 42 \\
\hline
\end{tabular}

Dari tabel di atas, tanpak aspek-aspek yang diamati pada kegiatan belajar mengajar (siklus II) yang dilaksanakn oleh guru dengan menerapkan metode pembelajarn kooperatif model TGT mendapatkan penilaian yang cukup baik dari pengamat. Maksudnya dari seluruh penilaian tidak terdapat nilai kurang. Namun demikian penilaian tesebut belum merupakan hasil yang optimal, untuk itu ada beberapa aspek yang perlu mendapatkan perhatian untuk penyempurnaan penerapan pembelajaran selanjutnya. Aspek-aspek tersebut adalah memotivasi siswa, membimbing siswa merumuskan kesimpulan/ menemukan konsep, dan pengelolaan waktu.

Dengan penyempurnaan aspek-aspek I atas alam penerapan metode pembelajarn kooperatif model TGT diharapkan siswa dapat menyimpulkan apa yang telah mereka pelajari dan mengemukakan pendapatnya sehingga mereka akan lebih memahami tentang apa ynag telah mereka lakukan.

Berikut disajikan hasil observasi akivitas guru dan siswa :

Tabel 6. Aktivitas Guru Dan Siswa Pada Siklus II

\begin{tabular}{clc}
\hline No & \multicolumn{1}{c}{ Aktivitas Guru yang diamati } & Presentase \\
\hline 1 & Menyampaikan tujuan & 6,7 \\
2 & Memotivasi siswa & 6,7 \\
3 & Mengkaitkan dengan pelajaran sebelumnya & 6,7 \\
4 & Menyampaikan materi/ langkah-langkah/ strategi & 11,7 \\
5 & Menjelaskan materi yang sulit & 11,7 \\
6 & Membimbing dan mengamati siswa dalam menemukan konsep & 25,0 \\
7 & Meminta siswa menyajikan dan mendiskusikan hasil kegiatan & 8,2 \\
8 & Memberikan umpan balik & 16,6 \\
9 & Membimbing siswa merangkum pelajaran & 6,7 \\
\hline No & \multicolumn{1}{c}{ Aktivitas siswa yang diamati } & Presentase \\
\hline 1 & Mendengarkan/ memperhatikan penjelasan guru & 17,9 \\
2 & Membaca buku suana & 12,1 \\
3 & Bekerja dengan sesama anggota kelompok & 21,0 \\
4 & Diskusi antar siswa/ antara siswa dengan guru & 13,8 \\
5 & Menyajikan hasil pembelajaran & 4,6 \\
6 & Menyajikan/ menanggapi pertanyaan/ ide & 5,4 \\
7 & Menulis yang relevan dengan KBM & 7,7 \\
8 & Merangkum pembelajaran & 6,7 \\
9 & Mengerjakan tes evaluasi & 10,8 \\
\hline
\end{tabular}

Berdasarkan tabel I di atas, tampak bahwa aktifitas guru yang paling dominan pada siklus II adalah membimbing dan mengamati siswa dalam menentukan konsep yaitu $25 \%$. Jika dibandingkan dengan siklus I, aktivitas ini mengalami peningkatan. Aktivitas guru yang mengalami penurunan adalah memberi umpan balik/evaluasi/ Tanya jawab $(16,6 \%)$, mnjelaskan materi yang sulit $(11,7)$. Meminta siswa mendiskusikan dan menyajikan hasil kegiatan $(8,2 \%)$, dan membimbing siswa merangkum pelajaran $(6,7 \%)$. 
Table 7. Nilai Tes Formatif Pada Siklus II

\begin{tabular}{|c|c|c|c|c|c|c|c|c|}
\hline \multirow{2}{*}{ No. Urut } & \multirow{2}{*}{ Skor } & \multicolumn{2}{|c|}{ Keterangan } & \multirow{2}{*}{\multicolumn{2}{|c|}{ No. Urut }} & \multirow{2}{*}{ Skor } & \multicolumn{2}{|c|}{ Keterangan } \\
\hline & & $\mathbf{T}$ & TT & & & & $\mathbf{T}$ & TT \\
\hline & \multicolumn{2}{|c|}{ Jumlah } & 950 & 10 & 3 & & & \\
\hline Jumlah & 1040 & 11 & 3 & & & & & \\
\hline \multicolumn{9}{|c|}{ Jumlah Skor 1990} \\
\hline \multicolumn{9}{|c|}{ Jumlah Skor Maksimal Ideal 2700} \\
\hline \multicolumn{9}{|c|}{ Rata-Rata Skor Tercapai 73,70} \\
\hline
\end{tabular}

Tabel 8. Rekapitulasi Hasil Tes Formatif Pada Siklus II

\begin{tabular}{clc}
\hline No & \multicolumn{1}{c}{ Uraian } & Hasil Siklus II \\
\hline 1 & Nilai rata-rata tes formatif & 73,70 \\
2 & Jumlah siswa yang tuntas belajar & 21 \\
3 & Persentase ketuntasan belajar & 77,78 \\
\hline
\end{tabular}

Dari tabel di atas diperoleh nilai ratarata prestasi belajar siswa adalah 73,70 dan ketuntasan belajar mencapai $77,78 \%$ atau ada 21 siswa dari 27 siswa sudah tuntas belajar. Hasil ini menunjukkan bahwa pada siklus II ini ketuntasan belajar secara klasikal telah mengalami peningkatan sedikit lebih baik dari siklus I. Adanya peningkatan hasil belajar siswa ini karena setelah guru menginformasikan bahwa setiap akhir pelajaran akan selalu diadakan tes sehingga pada pertemuan berikutnya siswa lebih termotivasi untuk belajar. Selain itu siswa juga sudah mulai mengerti apa yang dimaksudkan dan diinginkan guru dengan menerapkan metode pembelajaran kooperatif model TGT.

\section{Siklus III}

Pada tahap ini peneliti mempersiapkan perangkat pembelajaran yang terdiri dari rencana pelajaran 3, LKS 3, soal tes formatif 3 dan alat-alat pengajaran yang mendukung.

Pada akhir proses belajar mengajar siswa diberi tes formatif III dengan tujuan untuk mengetahui tingkat keberhasilan siswa dalam proses belajar mengajar yang telah dilakukan. Instrumen yang digunakan adalah tes formatif III. Adapun data hasil penelitian pada siklus III adalah sebagai berikut:

Tabel 9. Pengelolaan Pembelajaran Pada Siklus III

\begin{tabular}{|c|c|c|c|c|}
\hline \multirow{2}{*}{ No } & \multirow{2}{*}{ Aspek yang diamati } & \multicolumn{2}{|c|}{ Penilaian } & \multirow{2}{*}{ Rata-rata } \\
\hline & & P1 & $\mathbf{P 2}$ & \\
\hline \multirow{12}{*}{ I } & Pengamatan KBM & & & \\
\hline & A. Pendahuluan & & & \\
\hline & 1. Memotivasi siswa & 3 & 3 & 3 \\
\hline & 2. Menyampaikan tujuan pembelajaran & 4 & 4 & 4 \\
\hline & 3. Menghubungkan dengan pelajaran sebelumnya & & & \\
\hline & $\begin{array}{l}\text { 4. Mengatur siswa dalam kelompok-kelompok } \\
\text { belajar }\end{array}$ & & & \\
\hline & B. Kegiatan inti & 4 & 4 & 4 \\
\hline & 1. Mempresentasikan langkah-langkah metode & 4 & 4 & 4 \\
\hline & pembelajaran kooperatif & 4 & 4 & 4 \\
\hline & 2. Membimbing siswa melakukan kegiatan & & & \\
\hline & 3. Melatih keterampilan kooperatif & 4 & 3 & 3,5 \\
\hline & 4. Mengawasi setiap kelompok secara bergiliran & & & \\
\hline
\end{tabular}




\begin{tabular}{|c|c|c|c|c|}
\hline & $\begin{array}{l}\text { 5. Memberikan bantuan kepada kelompok yang } \\
\text { mengalami kesulitan }\end{array}$ & 3 & 3 & 3 \\
\hline & \multicolumn{4}{|l|}{ C. Penutup } \\
\hline & 1. Membimbing siswa membuat rangkuman & 4 & 4 & 4 \\
\hline & 2. Memberikan evaluasi & 4 & 4 & 4 \\
\hline II & Pengelolaan Waktu & 3 & 3 & 3 \\
\hline & \multicolumn{4}{|l|}{ Antusiasme Kelas } \\
\hline \multirow[t]{2}{*}{ III } & 1. Siswa antusia & 4 & 4 & 4 \\
\hline & 2. Guru antisias & 4 & 4 & 4 \\
\hline & Jumlah & 45 & 44 & 44,5 \\
\hline
\end{tabular}

Dari tabel di atas, dapat dilihat aspekaspek yang diamati pada kegiatan belajar mengajar (siklus III) yang dilaksanakan oleh guru dengan menerapkan metode pembelajaran kooperatif model TGT mendapatkan penilaian cukup baik dari pengamat adalah memotivasi siswa, membimbing siswa merumuskan kesimpulan/menemukan konsep, dan pengelolaan waktu.

Penyempurnaan aspek-aspek diatas dalam menerapkan metode pembelajaran kooperatif model TGT diharapkan dapat berhasil semaksimal mungkin.

Tabel 10. Aktivitas Guru dan Siswa Pada Siklus III

\begin{tabular}{clc}
\hline No & \multicolumn{1}{c}{ Aktivitas Guru yang diamati } & Presentase \\
\hline 1 & Menyampaikan tujuan & 6,7 \\
2 & Memotivasi siswa & 6,7 \\
3 & Mengkaitkan dengan pelajaran sebelumnya & 10,7 \\
4 & Menyampaikan materi/ langkah-langkah/ strategi & 13,3 \\
5 & Menjelaskan materi yang sulit & 10,0 \\
6 & Membimbing dan mengamati siswa dalam menemukan konsep & 22,6 \\
7 & Meminta siswa menyajikan dan mendiskusikan hasil kegiatan & 10,0 \\
8 & Memberikan umpan balik & 11,7 \\
9 & Membimbing siswa merangkum pelajaran & 10,0 \\
\hline No & \multicolumn{1}{c}{ Aktivitas siswa yang diamati } & Presentase \\
\hline 1 & Mendengarkan/ memperhatikan penjelasan guru & 20,8 \\
2 & Membaca buku & 13,1 \\
3 & Bekerja dengan sesama anggota kelompok & 22,1 \\
4 & Diskusi antar siswa/ antara siswa dengan guru & 15,0 \\
5 & Menyajikan hasil pembelajaran & 2,9 \\
6 & Menyajikan/ menanggapi pertanyaan/ ide & 4,2 \\
7 & Menulis yang relevan dengan KBM & 6,1 \\
8 & Merangkum pembelajaran & 7,3 \\
9 & Mengerjakan tes evaluasi & 8,5 \\
\hline
\end{tabular}

Berdasarkan tabel diatas tampak bahaw aktivitas guru yang paling dominan pada siklus III adalah membimbing dan mengamati siswa dalam menemukan konsep yaitu 22,6\%, sedangkan aktivitas menjelaskan materi yang sulit dan memberi umpan balik/evaluasi/tanya jawab menurun masing-masing sebesar (10\%), dan $(11,7 \%)$.
Aktivitas lain yang mengalami peningkatan adalah mengkaitkan dengan pelajaran sebelumnya (10\%), menyampiakan materi/strategi /langkah-langkah (13,3\%), meminta siswa menyajikan dan mendiskusikan hasil kegiatan (10\%), dan membimbing siswa merangkum pelajaran (10\%). Adapun aktivitas ynag tidak 
menglami perubahan adalah menyampaikan

tujuan $(6,7 \%)$ dan memotivasi siswa $(6,7 \%)$.

Table 11. Nilai Tes Formatif Pada Siklus III

\begin{tabular}{|c|c|c|c|c|c|c|c|}
\hline \multirow{2}{*}{ No. Urut } & \multirow{2}{*}{ Skor } & \multicolumn{2}{|c|}{ Keterangan } & \multirow{2}{*}{ No. Urut } & \multirow{2}{*}{ Skor } & \multicolumn{2}{|c|}{ Keterangan } \\
\hline & & $\mathrm{T}$ & TT & & & $\mathrm{T}$ & TT \\
\hline & & & & Jumlah & 1040 & 11 & 2 \\
\hline Jumlah & 1140 & 13 & 1 & & & & \\
\hline $\begin{array}{l}\text { Jumlah Sk } \\
\text { Jumlah Sk } \\
\text { Rata-Rata }\end{array}$ & $\begin{array}{l}180 \\
\text { Iaksima } \\
\text { Tercap }\end{array}$ & $\begin{array}{l}270 \\
74\end{array}$ & & & & & \\
\hline
\end{tabular}

Tabel 12. Hasil Tes Formatif Siswa pada Siklus III

\begin{tabular}{clc}
\hline No & \multicolumn{1}{c}{ Uraian } & Hasil Siklus III \\
\hline 1 & Nilai rata-rata tes formatif & 80,74 \\
2 & Jumlah siswa yang tuntas belajar & 24 \\
3 & Persentase ketuntasan belajar & 88,89 \\
\hline
\end{tabular}

Berdasarkan tabel diatas diperoleh nilai rata-rata tes formatif sebesar 80,74 dan dari 27 siswa yang telah tuntas sebanyak 24 siswa dan 3 siswa belum mencapai ketuntasan belajar. Maka secara klasikal ketuntasan belajar yang telah tercapai sebesar $88,89 \%$ (termasuk kategori tuntas). Hasil pada siklus III ini mengalami peningkatan lebih baik dari siklus II. Adanya peningkatan hasil belajar pada siklus III ini dipengaruhi oleh adanya peningkatan kemampuan guru dalam menerapkan metode pembelajaran kooperatif model TGT membuat siswa menjadi lebih terbiasa dengan pembelajaran seperti ini sehingga siswa lebih mudah dalam memahami materi yang telah diberikan.

\section{Pembahasan}

Melalui hasil penelitian ini menunjukkan bahwa pembelajaran kooperatif model TGT memiliki dampak positif dalam meningkatkan prestasi belajar siswa. Hal ini dapat dilihat dari semakin mantapnya pemahaman siswa terhadap materi yang disampaikan guru (ketuntasan belajar meningkat dari sklus I, II, dan III) yaitu masing-masing $66,67 \%, \quad 77,78 \%$, dan $88,89 \%$. Pada siklus III ketuntasan belajar siswa secara klasikal telah tercapai.

Berdasarkan analisis data, diperoleh aktivitas siswa dalam proses metode pembelajaran kooperatif model TGT dalam setiap siklus mengalami peningkatan. Hal ini berdampak positif terhadap prestasi belajar siswa yaitu dapat ditunjukkan dengan meningkatnya nilai rata-rata siswa pada setiap siklus yang terus mengalami peningkatan.

Berdasarkan analisis data, diperoleh aktivitas siswa dalam proses pembelajaran fisika pokok bahasan pengukuran dengan metode pembelajaran kooperatif model TGT yang paling dominant adalah bekerja dengan menggunakan alat/media, mendengarkan/memperhatikan penjelasan guru, dan diskusi antar siswa/antara siswa dengan guru. Jadi dapat dikatakan bahwa aktivitas siswa dapat dikategorikan aktif.

Sedangkan untuk aktivitas guru selama pembelajaran telah melaksanakan langkahlangkah metode pembelajaran kooperatif model TGT dengan baik. Hal ini terlihat dari aktivitas guru yang muncul di antaranya aktivitas membimbing dan mengamati siswa dalam mengerjakan kegiatan LKS/menemukan konsep, menjelaskan materi yang sulit, memberi umpan balik/evaluasi/tanya jawab dimana prosentase untuk aktivitas di atas cukup besar. 


\section{SIMPULAN DAN SARAN \\ Simpulan}

Dari hasil kegiatan pembelajaran yang telah dilakukan selama tiga siklus, dan berdasarkan seluruh pembahasan serta analisis yang telah dilakukan dapat disimpulkan sebagai berikut: (1) Pembelajaran dengan kooperatif model TGT memiliki dampak positif dalam meningkatkan prestasi belajar siswa yang ditandai dengan peningkatan ketuntasan belajar siswa dalam setiap siklus, yaitu siklus I $(66,67 \%)$, siklus II $(77,78 \%)$, siklus III $(88,89 \%)$. (2) Penerapan metode pembelajaran kooperatif model TGT mempunyai pengaruh positif, yaitu dapat meningkatkan motivasi belajar siswa yang ditunjukan dengan hasil wawancar dengan beberapa siswa, rata-rata jawaban menyatakan bahwa siswa tertarik dan berminat dengan metode pembelajaran kooperatif model TGT sehingga mereka menjadi termotivasi untuk belajar.

\section{Saran}

Dari hasil penelitian yang diperoleh dari uraian sebelumnya agar proses belajar mengajar matematika lebih efektif dan lebih memberikan hasil yang optimal bagi siswa, maka disampaikan saran sebagai berikut: (1) Untuk melaksanakan metode pembelajaran kooperatif model TGT memerlukan persiapan yang cukup matang, sehingga guru harus mampu menentukan atau memilih topik yang benar-benar bisa diterapkan dengan model kooperatif model TGT dalam proses belajar mengajar sehingga diperoleh hasil yang optimal. (2) Dalam rangka meningkatkan prestasi belajar siswa, guru hendaknya lebih sering melatih siswa dengan berbagai metode pembelajaran, walau dalam taraf yang sederhana, dimana siswa nantinya dapat menemukan pengetahuan baru, memperoleh konsep dan keterampilan, sehingga siswa berhasil atau mampu memecahkan masalah-masalah yang dihadapinya. (3) Untuk penelitian yang serupa hendaknya dilakukan perbaikanperbaikan agar diperoleh hasil yang lebih baik.

\section{DAFTAR PUSTAKA}

Ali, Muhammad. 1996. Guru Dalam Proses Belajar Mengajar. Bandung: Sinar Baru Algesindon.

Arikunto, Suharsimi. 1993. Manajemen Mengajar Secara Manusiawi. Jakarta: Rineksa Cipta.

Arikunto, Suharsimi. 1998. Prosedur Penelitian Suatu Pendekatan Praktek. Jakarta: Rineksa Cipta.

Arikunto, Suharsimi. 2001. Dasar-dasar Evaluasi Pendidikan. Jakarta: Bumi Aksara.

Arsyad, Azhar. 1997. Media Pembelajaran. Jakarta: PT. RajaGrafindo Persada.

Combs. Arthur. W. 1984. The Profesional Education of Teachers. Allin and Bacon, Inc. Boston.

Dahar, R.W. 1989. Teori-teori Belajar. Jakarta: Erlangga.

Departemen Pendidikan dan Kebudayaan, 1994. Petunjuk Pelaksanaan Proses Belajar Mengajar, Jakarta. Balai Pustaka.

Planner. victoria Dearcin University Press.

Margono, S. 1996. Metodologi Penelitian Pendidikan. Jakarta: Rineksa Cipta.

Mursell, James ( - ). Succesfull Teaching (terjemahan). Bandung: Jemmars.

Ngalim, Purwanto M. 1990. Psikologi Pendidikan. Bandung: PT. Remaja Rosdakarya.

Nur, Muhammad. 1996. Pembelajaran Kooperatif. Surabaya. Universitas Negeri Surabaya.

Purwanto, N. 1988. Prinsip-prinsip dan Teknis Evaluasi Pengajaran. Bandung. Remaja Rosda Karya.

Rustiyah, N.K. 1991. Strategi Belajar Mengajar. Jakarta: Bina Aksara.

Sardiman, A.M. 1996. Interaksi dan Motivasi Belajar Mengajar. Jakarta: Bina Aksara.

Soekamto, Toeti. 1997. Teori Belajar dan Model Pembelajaran. Jakarta: PAUPPAI, Universitas Terbuka.

Soetomo. 1993. Dasar-dasar Interaksi Belajar Mengajar. Surabaya Usaha Nasional. 